\title{
ENVIRONMENTAL COST REPORTING AND PERFORMANCE OF NIGERIAN OIL AND GAS DOWNSTREAM
}

\author{
Giami Isaac Baribefe \\ Department of Accountancy, School of Financial Studies, Port Harcourt Polytechnic, \\ Rumuola, Port Harcourt
}

Email: giamibaribefe@gmail.com

Cite this article:

Giami Isaac Baribefe (2021), Environmental Cost Reporting and Performance of Nigerian Oil and Gas Downstream. African Journal of Accounting and Financial Research 4(2), 26-54. DOI:

10.52589/AJAFR/VQRP7G8 $\mathrm{K}$.

\section{Manuscript History}

Received: 24 March 2021

Accepted: 21 April 2021

Published: 27 April 2021

\section{Copyright () 2020 The} Author(s). This is an Open Access article distributed under the terms of Creative Commons AttributionNonCommercialNoDerivatives 4.0 International (CC BY-NC-ND 4.0), which permits anyone to share, use, reproduce and redistribute in any medium, provided the original author and source are credited.
ABSTRACT: This research work examined the relationship between environmental cost reporting and performance of Nigerian oil and gas downstream companies quoted on the Nigerian stock exchange for the period 2011 to 2020. The study adopted historical data design and census sampling techniques was used in studying the entire population. Four hypotheses were tested using multiple regression analyses with the help of ordinary least square and the findings revealed that, amount spent on waste management /remediation has a negative and insignificant relationship with growth in sales volume as well as return on asset. Amount spent on compensation also has negative and insignificant relationship with both growth in sales volume and return on assets. It was however recommended that oil and Gas companies continue to manage their waste and include community development in their decision making in line with global best practices to keep them socially acceptable as these will ensure a symbiotic relationship among the various stakeholders.

KEYWORDS: Environmental Accounting, Firms' Performance, Waste Management, Remediation Cost, Growth in Sales Volume. 


\section{INTRODUCTION}

The quest for profit and development has led to the massive destruction and degradation of the environment and natural capital. Nigeria being a developing nation, endowed with abundant Natural resources such as Petroleum, Natural gas, Coal lime etc. is not devoid of environmental degradation. This of course is a threat to development. Development and Environment are intertwined and one should not be ignored to the detriment of the other. (Myers 1989).

Infact, in an attempt to tap her natural resources to enhance its economic development and well-being of the citizenry, finds herself experiencing an array of pollutants including carbon dioxide, warming and gas flaring, more recently the soot we now experience in some part of Port Harcourt, oil spillage and other related problems, deforestation etc. This of course is a threat to development.

The adverse effect of economic development on environment has therefore become a matter of great public concern all over the world. Accountants as custodians of economic development can no longer shut their eyes against these environmental issues on business. A careful assessment of the cost and benefits of environmental damages is necessary to find the tolerance limit between environmental degradation and the required level of development.

Therefore, Environmental Accounting has to do with the Identification, Measurement and Allocation of environmental costs and the integration of these costs into business activities and encompasses the way of communicating such information to the companies' stakeholders (Magara, Aming'a \& Momanyi 2015). It provides a common framework for organizations to identify and account for their past, present and future environmental cost to support management decision making, control and public disclosure (KPMG and Unep 2006).

It is a comprehensive approach to ensure good corporate governance that includes transparency in its societal activities (Gray, Bebbington and Walter 1993).

One may think that paying more attention to the environment may increase cost and reduce profit. And that is while the classical economic theory believes that the firm has one and only one objective which is to maximize wealth profit. But recent discourse on the emerging environmental challenges suggests that this position present a naïve understanding of environmental matters.

In fact, Akhaiyea (2009) believes that corporate negligence and avoidance of environmental costing leave gap in financial information reporting and as such do not present a fair view that it may create actual or contingent liabilities which may pose a threat to asset values.

The increasing concern about environmental degradation, resource depletion and the sustainability of economic activity have made the development of environmental accounting and reporting an area of significant interest in Nigeria since companies may be determined not only by the products or services, they deal with but also by the complexity of their environment. (Adediran \& Alade 2013)

Obemene \& Olaoye (2009) pointed out that the haste to develop did not incorporate pollution control and waste management into environmental management plan. Even the 
environmental laws regarding pollution and waste management seem to be inadequate or where they exist, remain to a large extent unenforceable

It may appear that greater attention to environmental matters may lead to an increase in costs and hence lower profits. Environmental costs and obligations are significantly growing as the world is becoming more environmentally conscious. Public corporations are being held more responsible and accountable to the society. Many people are willing to pay more for a product that is environmentally friendly, (Chouhan M. 2005).

It cannot be denied that environmental Accounting and reporting thereof is of paramount importance today.

Accounting for environment helps in accurate assessment of costs and benefits of environmental preservation measures of companies (Schaltegger, 2000). It involves the identification, measurement and allocation of environmental costs and integration of these costs into business and encompasses the way of communicating such information to the companies' stakeholders (Magara, Aminga and Momanyi, 2015).

Companies and other organizations are required to have accountability to stakeholders, such as consumers, business partners, employees, investors, local residents, and administration when utilizing environmental resources i.e. public goods, for their activities. Disclosure of environmental accounting helps companies and other organizations boost their public trust and confidence and are associated with receiving a fair assessment (EAG, 2005).

Bewley and Li (2000), appealed to voluntary disclosure theory to examine the environmental disclosures of Canadian manufacturing firms. They used the Wiseman index to measure the 1993 annual report disclosures of 188 firms and industry membership to proxy for pollution propensity. They found out that firms with a higher pollution propensity and greater media coverage of their environmental performance are more likely to disclose general environmental information.

Al-Tuwaiji et'al (2004), employed simultaneous equations approach to investigate the relations among environment disclosure, and environmental performance and economic performance. They use proxy for environmental performance using the percentage of total waste generated recycled as identified using the TRI database as measure environmental disclosure using content analysis in four categories, potential responsible parties' designation, toxic waste, oil and chemicals spills, and environmental fines and penalties, disclosures which are largely non-discretionary. Based on these proxies, they documented a positive association between environmental performance and environmental disclosures.

Similarly, the works of Bassey et'al (2013), Adediran and Alade (2013) and Daniel et'al (2013) concluded that environmental cost have positive and significant relationship with organization performance after using Return on Capital Employed, Earnings Per Share, Net Profit Margin and Dividend Per Share as their proxies for performance analyzing them using Spearman rank product movement and multiple regression analyses.

However, no much work has been done on environmental accounting and performance of Oil and Gas companies in Nigeria using amount spent on waste management / remediation and compensation cost as proxies for environmental accounting and growth in sales and returns 
on assets as proxies for performance up to the year 2020. It is based on this vacuum that the researcher's attention was drawn to this topic.

\section{Aim and Objectives of the Study}

The main objective of this study is to investigate the relationship between environmental cost reporting and performance of downstream oil and gas companies in Nigeria. Other specific objectives include:

i) To determine the relationship between waste Management and Remediation cost and growth in sales volume.

ii) To determine the relationship between waste Management and Remediation cost and return on assets.

iii) To examine the relationship between environmental compensation cost and growth in sales volume.

iv) To determine the relationship between environmental compensation cost and return on assets.

\section{Research Questions}

This study will provide answers to the following research questions.

i) To what extent does amount spent on Waste Management and Remediation influence growth in sales volume?

ii) Is there any relationship between the amount spent on waste management and remediation on return on assets?

iii) To what extent does the amount spent on environmental compensation influence the growth in sales volume.

iv) Is there any relationship between amount spent on environmental compensation and return on assets?

\section{Research Hypothesis}

H01: There is no relationship between Amount Spent on waste management/remediation and growth in sales volume.

H02: There is no relationship between the amount spent on waste management / remediation and return on assets.

Ho3:- There is no relationship between amount spent on compensation and growth in sales volume

Ho4: There is no relationship between amount spent on compensation and Return on Assets. 


\section{LITERATURE REVIEW}

\section{Theoretical Review}

\section{Legitimacy theory}

Legitimacy is a generalized perception or assumption that the actions of a entity are desirable, proper or appropriate within some socially constructed system of norms, values and definitions (Suchman, 1995). The theory posits that a company's performance is legitimate when it is judged to be fair and worthy of support that is, when it is socially accepted (Magara, Aminga \& Momanyi, 2015).

Legitimacy gaps arise when societal expectations of the firm's behaviours differ from societal perceptions of its behavior. A process of legitimating may be engaged in by a company either to gain or to extend legitimacy, to maintain its level of current legitimacy, or to repair or to defined its lost or threatened legitimacy. (O’Dovovan, 2012).

Deegan, (2002) argues that where managers perceive that organization's operations do not commensurate with the social contract then, pursuant to legitimacy theory, remedial strategies are predicted. Because, the theory is based on perceptions, any remedial strategies implemented by mangers, to have effect on external parties, must be accompanied by disclosure.

\section{Stakeholder Theory}

The basic proposition of the stakeholder's theory is that the firm's success is dependent upon the successful management of all the relationships that a firm has with its stakeholders a term originally introduced by Stanford research institute (SRI) to refer to those groups without whose support the organization would cease to exist. (Freeman, 1984) In a follow-up study, Freeman (1984) revisited stakeholder theory and redefined stakeholders as any individual or group who has an interest in the firm because he (or she) can affect or is affected by the firm's activities. Carroll (1991) defines a stakeholder as any individual or group who can or is affected by the actions, policies, practices or goals of the organization.

\section{Conceptual Review}

\section{The Concept of Environment Accounting}

Environmental Accounting is a system that attempts to make the best possible quantitative assessment (in terms of either money or physical units) of the costs and benefits to an enterprise due to the environmental preservation activities that it undertakes (Pramanik, Shil \& Das, 2007), Environmental Accounting can more accurately identify true costs by clarifying the environmental impacts caused by material acquisition and processing, manufacturing, sales distribution, use, maintenance and disposal.

It is a comprehensive approach to ensure good corporate governance that includes transparency in its societal activities (Gray, Bebbington \& Watter, 1993). Environmental Accounting provides a common framework for organizations to identify and account for past, present and future environmental cost to support management decision making, control and public disclosure (KPMG \& UNEP, 2006). 


\section{Environmental Accounting and Reporting}

Financial reporting presents a variety of information, which might also include social and environmental issues; and given that corporate financial performance is related, in part, to a company's environmental performance, stakeholders are increasingly paying more attention to environmental issues in a company. (Ayoid, Nosakhare and Chijoke, 2015).

Akhaiyea (2009) notes that in the context of National income accounting environmental accounting indicates natural resource accounting which is concerned with the statistics of a nations or region's consumption of natural resource. It also takes into account the extent, quality and valuation of natural resources which are either renewable or nonrenewable.

In the context of Financial Accounting, Environmental Accounting connotes the preparation of financial reports to external users using Generally Accepted Accounting Principles (GAAP). This is financial reporting to external users conveying the impact on environment and activities impacting on eco-efficiency.

Makori and Jagongo (2013), in a study on Indian companies, posits that environmental reporting is broadly classified into mandatory and voluntary disclosure, with most of the companies opting for voluntary environmental reporting in the form of satellite reporting, sustainability reporting, global reporting initiative and internet reporting.

According to Okoye and Ngawakwe (2004) as cited in Ayoib, Nosokhare and Chijoke (2015), environmental accounting at corporate level deals with identification, measurement recognition and disclosure of environmental costs, liabilities and contingencies in the financial records of a company for the benefit of various internal and external stakeholders. In this regard, the United Nations and International institute for sustainable Development, respectively, have argued for the need for the evolution of what may be readily termed "Natural Resource Accounts" which should incorporate the impairment of natural and environmental resources and thus provide a sustainable development profit and loss statement based on sustainable development accounting principles or and environmentally adjusted "Value added statement" (Macve and Carey, 1992).

According to Adediran \& Alade (2013), Environmental Reporting is in stages ranging from ad-hoc comment in the annual report to stand-alone environment reports. Environmental investments is no longer seen as an additional cost but they are seen as part of corporate social responsibility therefore, environmental reports are seen as necessary in communicating with stakeholders to address their environmental concerns.

Companies are realizing that it is their corporate responsibility to achieve sustainable development whereby they meet the present needs without compromising the ability of future generations to meet their needs. Economic growth is important for both shareholders and stakeholders alike in that it provides the condition in which protection of the environment can best be achieved.

\section{Environmental Accounting in Nigeria}

Oil \& Gas activities within the environment have resulted to resources depletion and environmental degradation. These activities have further led to the depletion of ozone layer, thereby causing imbalance in the environmental system. 
Research Carried Out by the Federal Environmental Protection Agency (FEPA) as cited by Aina (1991), indicates that Nigeria is confronted by major environmental problems, the most of them include:

Water Pollution: this is caused by illegal release of industrial liquid waste to streams, Rivers and open drains.

Oil \& Gas Pollution: This is caused by oil and gas transportation and exploration activities carried out in oil \& gas producing regions.

Loss of Biodiversity: This is directly caused by fragmentation, degradation and loss of habitat, the over exploitation of natural resources; pollution and others.

Industrial Pollution: This includes both solid and liquid waste pollution. In Nigeria, most industries do not dispose their solid waste properly and industrial liquid waste is still discharged in some cases into places that are harmful to harmful to their lost communities.

Land Degradation: Land degradation according to Wikipedia 2011 is a human, induced of natural process which negatively affect the capacity of land function affectively within on ecosystem by accepting, storing and recycling water, energy, and nutrients. The causes of land degradation are identified as anthropogenic and mainly agricultural related. They include; land clearing and deforestation, agricultural depletion of soil nutrient, urban conversion, irrigation and pollution.

Dangerous hydrocarbons are emitted into the air whenever there is oil spillage or leakages. This is dangerous to man and other organisms. Various effects of different hydrocarbons on health include benzene which on chronic exposure may cause leukemia, and birth defects, ethyl benzene which may cause dizziness, slower reflexes, loss of consciences and death; zylene may cause damages to a developing foetus, liver, kidney, skin, eyes and bone marrow (Mabogunje, 2007) (Olorunfemi and Jimoh, 2000).

Nigeria as a developing nation with her abundant natural resources (Oil and Gas Products) is facing difficult challenges in the control of environmental degradation. Oil exploration and government activities may have reduced the quality and usefulness of life through gas flaring, industrial pollution, oil spillage, deforestation, etc. the researcher observes that most of the oil producing communities continues to dwell in abject poverty, despite the fact that huge amount of the nation's resources is obtained from there. The multinational companies that explore the crude oil and its by - products from these communities often fail to consider that they should pay adequate attention to the social demands of the host communities and become environmentally friendly with them.

The oil producing communities often find it very difficult to cope with their natural environment because of the oil spillage, industrial pollution, etc from their foreign companies. The impact of their environmental pollution to the host communities cannot be over-emphasized. In line with the stakeholder theory, one would ask if these companies are doing their best to ensure enhancement of quality of life of host communities and also ensure adequate environmental control measures in line with international regulatory laws.

However, the searches for profitability by these oil \& gas companies have many such companies exceedingly rich to the detriment of the environment. 
Consequently, the increase concern about environmental degradation, resource depletion and the sustainability of economic activities has made Environmental Accounting and Reporting an area of significance interest in the recent times, in Nigeria, thus Environmental Accounting is a new concept that tries to recognize the side effects of production and consumption on the physical environment (Adediran and Atu, 2010).

These effects of production and consumption should be recognized in the financial statements of organizations.

\section{Benefits of Environmental Accounting}

The benefits of understanding an environmental accounting initiative is that the identification and greater awareness of environment related costs often provides the opportunity to find ways to reduce or avoid these costs, whilst also improving environmental performance (William, 1999, Tapang, Bassey \& Bessong, 2012, Tilt, 1994).

Richardson (1999) identified that more elaborately; environmental accounting is an effective tool for placing environmental issues firmly on top management agenda, providing useful data to inform environmental and financial manager's decision-making and concretely demonstrating environmental commitment to stakeholders.

The environmental protection Agency (EPA) adds the following benefits:

i. Many environmental problems can be significantly reduced or eliminated as a result of effective decisions.

ii. Environmental cost (and potential saving) may be obscured in overhead or otherwise overlooked

iii. Environmental cost can be offset by generating revenues through sales of wasted or byproducts or recycling them

iv. Understanding of environment costs can promote more accurate costing and pricing of products.

v. Competitive advantages with customers can result to processes, products and services which can be demonstrated to be environmentally friendly.

vi. Accounting for environmentally cost and performance can support a company's development and operation of an overall environmental management system.

\section{Waste Management / Remediation Cost}

Every establishment produces waste: it could be either industrial or human and could cause environmental and human hazard if not properly managed.

Waste management therefore, means to prevent the negative effect of waste. It consists of; reduction of waste, reuse of waste, recycling of waste, compositing, energy recovery and final disposal (Addul-Rahman 2015; Bontoux \& Leone 1997), to sustain profit, the environment which business operates must be properly taken care of. A neglected environment may likely lead to unfavorable business environment. This may also lead to unnecessary additional cost to business operation. 
It is therefore necessary for downstream companies to manage their waste and disclose them in their accounts.

Remediation on the other hand is a total clean-up of contaminants.

\section{Environmental Compensation Cost}

Environmental impacts are increasing due to human activities. The overuse of the benefits nature provides us is the direct result of our failure to put a price on these benefits. One way of addressing this is to require environmental compensation measures that offset the loss associated with the damage resources. Environmental compensation is provided in the form of resource-based (may not be monetary) payments that protect enhance, restore or otherwise improve similar resources.

This concept is anchored on polluter pays principle (PPP). The primary benefit of compensation is to reduce the social welfare loss associated with a continued decline in the benefits nature provides us; Biodiversity and ecosystem services. Compensation helps to reduce this decline by implicitly "pricing" these benefits and creating an incentive for actors to incorporate these values into their daily decision-making. The failure to price nature's benefits leads them to appear "value-less" under the current business as usual scenario.

\section{Return on Assets}

Return on Asset is an indicator of how profitable a company is relative to its total assets. ROA gives an idea as to how efficient management is at using its asset to generate earnings. It is calculated by dividing a company's annual earnings by its total assets. ROA is displayed as a percentage.

Formula:

$$
\text { ROA }=\frac{\text { Net Profit }}{\text { Total Assets }}
$$

ROA tells you what earnings were generated from invested capital (assets)

\section{Growth in Sales Volume}

Sales volume according to the business dictionary is the quantity or number of goods sold or services sold in the normal operations of a company in a specified period. Profits therefore depend on growing sales and managing cost. To know whether there is growth in the sales volume, you need to measure it between two periods- which is the difference between the current sales minus (-) the past sales divided by the past sales. 
formula;

$\mathrm{GSV}=\frac{\mathrm{CS}-\mathrm{PS}}{\mathrm{PS}}$

Where; CS -Current Sales

$$
\text { PS - Present Year Sales }
$$

\section{Empirical Studies}

Daniel and Ambrose (2013) carried out a study on environmental accounting and firm's profitability using amount spent on environmental protection as their proxy for independent variable and ROCE, NPM, DPS and EPS as proxies for firm's profitability - independent variable. The key findings of their studies show that there is a significant negative relationship that exists between environmental accounting and firm's performance after using Least Square Regression Method to analyze their data.

Norhasimah et' al (2015) found a significant relationship between total environment cost accounting disclosure and profit margin but insignificant relationship with ROA, ROE and EPS when they carried out a study on the effects of environmental disclosure on financial performance in Malaysia, using multiple regression analyses.

Holm and Richardson (2008) studied the effect of environmental disclosure on investment decisions. The results suggest that environmental information disclosure influences investment allocation decisions. This finding would imply that companies that are apathetic to their environmental costs or responsibility might experience eventual crashes on their stock price if their investors are rational in considering the future value of the firm based on its present state of environmental responsibility.

Al-Tuwaiji et'al (2004) employed simultaneous equations approach to investigate the relationship among environmental performance and economic performance. They used proxy for environmental performance using the percentage of total wasted generated recycled and measure environmental disclosure using content analysis in four categories, potential responsible parties' designation, toxic waste, oil and chemicals spills and environmental fines and penalties. Their findings documented a positive association between environmental performance and environmental disclosure.

Bassey et' al (2013), examined the impact of environmental accounting and reporting on organizational performance of Oil and Gas companies. Their study shows that environmental accounting cost management positively influence firm's profitability after using Pearson's moment correlation analysis statistics for their analysis.

Adediran and Alade (2013) concluded in their study that environmental accounting has significant relationship with ROCE, EPS, NPM and DPS - indices for corporate performance though either negative or positive after using multiple regression analysis.

Ifurueze, Lyndon and bingilar (2013), revealed that environmental cost in oil sector in Nigeria has significant but negative impact on corporate performance after using community development cost, employees' safety cost and waste management costs as proxies for environmental cost and analyzed using multiple regressions. Their findings indicated that a 
unit increase in waste management cost decreased the profit by .552 and a unit increase in community development cost also decreased the profit by .45 .

\section{MATERIALS AND METHODS}

The design for this study is historical data design. The essence was to obtain historical data for the study and analyze them.

The population for this study therefore, includes all the oil and gas companies quoted on the Nigeria stock exchange. They are:

Forte Oil Plc

Conoil Plc

Oando Plc

Mrs Plc

Total Nig. Plc

Mobil Nig. Plc

Eternal Oil and Gas Plc

Beco Petroleum Plc

Capital Oil Plc

Rak Unity Petroleum Plc

The sample size for this study is Ten (10) oil and gas companies. Census sampling technique was used to study the entire population.

The major source of data for this work is secondary data. They include; review of relevant literature already documented facts from statistical fact Books, Annual Reports and Financial statements.

\section{Method of Data Collection}

This study depended on secondary data. Relevant data was collected from the Nigerian Stock Exchange and the website of the companies involved.

\section{Model Specification}

$\mathrm{Y}=\mathrm{F}\left(\mathrm{X}_{1} \mathrm{X}_{2}\right)$

Where $\mathrm{Y}$ is the dependence variable (Performances) and $\mathrm{X}_{1} \mathrm{X}_{2}$ are the independence variable (Environmental Accounting). 
Therefore:

$\begin{array}{ll}\mathrm{ROA} & =\beta_{0}+\beta_{1} \mathrm{WMRC}+\mathrm{b}_{2} \mathrm{ECC}+\mathrm{e}--- \text { eqn (i) } \\ \mathrm{GSV} & =\beta_{0}+\beta_{1} \mathrm{WMRC}+\mathrm{b}_{2} \mathrm{ECC}+\mathrm{e}-- \text { eqn (ii) }\end{array}$

Where

$\beta_{0} \quad=$ Constant

$\beta_{1} \beta_{2} \quad=$ Coefficient of the regression

$\mathrm{e} \quad=$ Error term

WMRC = Waste Management and Remediation cost

ECC = Environmental compensation cost

ROA = Return on Assets

GSV = Growth in sales volume

\section{Method of data analyses}

This study employed descriptive statistics to present the data collected. To test the hypotheses, multiple regressions with the help of ordinary least square statistics were used.

\section{RESULTS AND DISCUSSION}

\section{Presentations of Data}

Table 1: Growth in Sales Volumn of 10 Petroleum Marketing Firms in Nigeria 20112020

\begin{tabular}{|c|l|r|r|r|r|r|r|r|r|r|r|}
\hline S/ NO & FIRMS & $\mathbf{2 0 1 1}$ & $\mathbf{2 0 1 2}$ & $\mathbf{2 0 1 3}$ & $\mathbf{2 0 1 4}$ & $\mathbf{2 0 1 5}$ & $\mathbf{2 0 1 6}$ & $\mathbf{2 0 1 7}$ & $\mathbf{2 0 1 8}$ & $\mathbf{2 0 1 9}$ & $\mathbf{2 0 2 0}$ \\
\hline 1 & FORTE OIL PLC & 0.25 & 0.50 & 0.04 & -0.21 & -0.07 & -0.2 & 0.41 & 0.33 & -0.27 & 0.19 \\
\hline 2 & OANDO PLC & -0.01 & -0.91 & -0.38 & 0.03 & 0.86 & -0.1 & -0.20 & 1.41 & -0.40 & -0.42 \\
\hline 3 & TOTAL NIG. PLC & 0.09 & 0.29 & 6.53 & -0.10 & 0.08 & 0.25 & 0.09 & 0.01 & -0.13 & 0.39 \\
\hline 4 & MRS PLC & 0.10 & -0.33 & 0.53 & 2.30 & -0.04 & 0.12 & 0.10 & 0.05 & -0.06 & 0.26 \\
\hline 5 & MOBIL NIG. PLC & 0.07 & 0.22 & -0.07 & -0.06 & 0.06 & 0.30 & -0.03 & 0.01 & -0.19 & 0.47 \\
\hline 6 & CONOIL PLC & -0.04 & 0.43 & -0.18 & 0.01 & 0.53 & -0.1 & 0.06 & -0.10 & -0.35 & 0.03 \\
\hline 7 & BECO PET.PLC & 0.19 & 0.21 & 0.17 & -0.3 & 0.62 & -0.7 & -0.52 & -0.42 & - & - \\
\hline & ETERNA & & & & & & & & & & \\
8 & OIL\&GAS & 0.39 & 1.45 & -0.23 & 0.53 & 1.90 & 1.18 & 0.09 & -0.16 & 0.12 & 0.16 \\
\hline 9 & RAK UNITY PET. & - & - & - & - & - & -1.0 & - & -0.99 & 0.89 & -0.08 \\
\hline & CAPITAL OIL & & & & & & & & & & \\
10 & PLC & 0.62 & 0.17 & 3.43 & -0.87 & 8.05 & 0.47 & 0.56 & -0.92 & -0.46 & -0.26 \\
\hline
\end{tabular}

Source: Firms' Annual Report \& Accts Gsv=Cs-Ps/Ps 
Table: 2: Return on Assets of 10 Pet. Marketing Firms in Nigeria from 2011-2020

\begin{tabular}{|r|l|r|r|r|r|r|r|r|r|r|r|}
\hline $\begin{array}{l}\text { S/ } \\
\text { NO }\end{array}$ & FIRMS & $\mathbf{2 0 1 1}$ & $\mathbf{2 0 1 2}$ & $\mathbf{2 0 1 3}$ & $\mathbf{2 0 1 4}$ & $\mathbf{2 0 1 5}$ & $\mathbf{2 0 1 6}$ & $\mathbf{2 0 1 7}$ & $\mathbf{2 0 1 8}$ & $\mathbf{2 0 1 9}$ & $\mathbf{2 0 2 0}$ \\
\hline 1 & FORTE OIL PLC & 0.59 & 0.47 & $(0.23)$ & $(0.07)$ & 0.43 & 0.02 & 0.04 & 0.03 & 0.04 & 0.02 \\
\hline 2 & OANDO PLC & 0.02 & 0.03 & 0.01 & 0.04 & 0.01 & 0.04 & 0.01 & 1.04 & $(0.56)$ & 0.41 \\
\hline 3 & TOTAL NIG. PLC & 0.28 & 0.10 & 0.07 & 0.09 & 0.06 & 0.06 & 0.06 & 0.04 & 0.04 & 0.10 \\
\hline 4 & MRS OIL & 0.36 & $(0.06)$ & 0.24 & 0.08 & 0.02 & 0.01 & 0.02 & 0.02 & 0.03 & 0.05 \\
\hline 5 & MOBIL NIG. PLC & 0.15 & 0.22 & 0.29 & 0.31 & 0.21 & 0.13 & 0.13 & 0.19 & 0.12 & 0.19 \\
\hline 6 & CONOIL PLC & 0.17 & 0.03 & 0.05 & 0.06 & 0.04 & 0.08 & 0.08 & 0.09 & 0.03 & 0.04 \\
\hline 7 & BECO PET. PLC & 0.08 & 0.49 & 0.04 & 0.08 & 0.06 & 0.70 & -0.17 & -0.08 & - & - \\
\hline 8 & ETERNA OIL \& GAS & 0.41 & 0.04 & 0.20 & 0.10 & 0.19 & 0.02 & 0.03 & 0.06 & 0.04 & 0.04 \\
\hline 9 & RAK UNITY PET. & - & - & - & - & - & 0.10 & 0.02 & 0.04 & 0.12 & 0.03 \\
\hline 10 & CAPITAL OIL & $(0.02)$ & $(0.03)$ & $(0.19)$ & $(0.13)$ & $(0.02)$ & $(0.01)$ & $(0.25)$ & $(0.07)$ & $(0.03)$ & $(0.26)$ \\
\hline & & & & & & & & & & & \\
\hline
\end{tabular}




\section{Table 3: Environmental Compensation Cost of 10 Petroleum Marketing Firms from 2011-2020}

\begin{tabular}{|c|c|c|c|c|c|c|c|c|c|c|c|}
\hline $\begin{array}{l}\mathbf{S} / \\
\mathbf{N}^{\prime}\end{array}$ & FIRMS & 2011 & 2012 & 2013 & 2014 & 2015 & 2016 & 2017 & 2018 & 2019 & 2020 \\
\hline 1 & Forte Oil Plc & $2,000,000$ & $3,000,000$ & $3,400,000$ & $3,000,000$ & $3,200,000$ & $3,000,000$ & $4,000,000$ & $5,700,000$ & $6,870,520$ & $7,120,227$ \\
\hline 2 & Mobil Nig. Plc & $1,649,079$ & $1,833,082$ & $1,989,714$ & $1,853,098$ & $2,200,958$ & $2,498,075$ & $3,661,186$ & $5,622,018$ & $8,784,089$ & $8,994,598$ \\
\hline 3 & Conoil Plc & $7,500,000$ & $7,500,000$ & $8,700,000$ & $9,200,000$ & $9,700,000$ & $11,000,000$ & $12,750,000$ & $14,950,338$ & $14,550,620$ & $14,825,931$ \\
\hline 4 & Oando Plc & $1,392,409$ & $1,515,738$ & $3,478,348$ & $8,082,474$ & $10,455,432$ & $17,862,112$ & $12,843,200$ & $19,093,423$ & $19,693,562$ & $19,790,167$ \\
\hline 5 & MRS Plc & $1,870,000$ & $1,365,000$ & $1,000,000$ & $2,600,000$ & $2,830,000$ & $3,223,000$ & $3,400,000$ & $3,820,000$ & $4,791,800$ & $4,874,454$ \\
\hline 6 & Total Plc & $3,000,000$ & $5,410,000$ & $6,588,000$ & $8,378,000$ & $10,290,000$ & $14,818,000$ & $32,546,514$ & $27,080,764$ & $34,893,045$ & $35,188,206$ \\
\hline 7 & $\begin{array}{l}\text { Eterna Oil \& Gas } \\
\text { Plc }\end{array}$ & 800,000 & 870,000 & $1,300,000$ & $1,464,000$ & $1,734,400$ & $2,796,500$ & $3,902,300$ & $3,816,011$ & $3,273,353$ & $3,583,137$ \\
\hline 8 & Beco Petroleum Plc & $1,006,654$ & $1,107,321$ & $1,118,100$ & $1,133,391$ & $1,165,841$ & $1,189,076$ & $1,147,304$ & $1,520,000$ & $1,716,976$ & $1,858,488$ \\
\hline 9 & Rak Unity Pet. Plc & $1,700,000$ & $1,500,000$ & $2,300,000$ & $2,000,000$ & $1,800,000$ & $2,000,000$ & $2,500,000$ & $3,000,000$ & $3,155,000$ & $3,200,000$ \\
\hline 10 & Capital Oil Plc & $1,460,000$ & $1,540,000$ & $1,655,000$ & $1,700,000$ & $1,670,000$ & $1,720,000$ & $1,800,000$ & $1,850,000$ & $1,876,000$ & $1,920,000$ \\
\hline
\end{tabular}

Source: Firms Annual Report \&Accounts 


\section{Table 4: Cost of Waste Management Of 10 Petroleum Marketing Firms From 2011-2020}

\begin{tabular}{|c|c|c|c|c|c|c|c|c|c|c|c|}
\hline $\mathbf{S} / \mathbf{N}^{\prime}$ & FIRMS & 2011 & 2002 & 2003 & 2014 & 2015 & 2016 & 2017 & 2018 & 2019 & 2020 \\
\hline 1 & Forte Oil Plc & $1,298,761$ & $1,799,390$ & $2,288,956$ & $1,512,794$ & $1,517,937$ & $2,069,865$ & $1,845,556$ & $1,085,383$ & $1,923,476$ & $1,085,383$ \\
\hline 2 & Mobil Nig. Plc & $1,648,970$ & $1,649,019$ & $1,833,082$ & $1,989,714$ & $2,084,860$ & $1,894,106$ & $2,189,638$ & $2,111,866$ & $4,470,091$ & $6,272,004$ \\
\hline 4 & Oando Plc & $1,100,293$ & $1,456,365$ & $1,868,476$ & $1,483,300$ & $1,110,455$ & $1,274,862$ & $1,826,713$ & $1,603,589$ & $1,752,128$ & $1,939,965$ \\
\hline 5 & MRS Plc & 820,819 & 712,129 & 808,013 & 908,290 & 933,073 & 923,383 & $1,563,330$ & $1,589,911$ & $1,555,932$ & $1,498,434$ \\
\hline 7 & $\begin{array}{l}\text { Eterna Oil \& } \\
\text { Gas Plc }\end{array}$ & $1,742,101$ & $1,205,181$ & $1,376,584$ & $1,948,289$ & $1,608,981$ & $1,951,863$ & $1,870,363$ & $1,442,836$ & $1,416,667$ & $1,427,527$ \\
\hline 8 & $\begin{array}{l}\text { Beco Petroleum } \\
\text { Plc }\end{array}$ & $1,732,820$ & $1,070,302$ & $1,341,666$ & $1,182,155$ & $1,914,324$ & $1,732,820$ & $1,594,125$ & $3,188,250$ & $3,476,021$ & $3,526,680$ \\
\hline 9 & $\begin{array}{l}\text { Rak Unity Pet. } \\
\text { Plc }\end{array}$ & $1,240,000$ & $1,129,000$ & $1,846,000$ & $1,257,000$ & $1,445,000$ & $1,389,000$ & $1,086,000$ & $1,380,000$ & $3,820,000$ & $2,850,000$ \\
\hline
\end{tabular}

Source: Firms Annual Report \& Accounts 
African Journal of Accounting and Financial Research

ISSN: 2682-6690

Volume 4, Issue 2, 2021 (pp. 26-54)

www.abjournals.org

\section{Descriptive Statistics}

The descriptive statistics of the variables used within the scope of this study is presented in table 4.1. The data covers a period of ten years from $2011-2020$

Table: 5: Descriptive Statistics

\begin{tabular}{|l|r|r|r|r|r|}
\hline & $\mathrm{N}$ & Minimum & Maximum & \multicolumn{1}{c|}{ Mean } & Std. Deviation \\
\hline waste & & & & & \\
management/remediatio & 100 & 188543.00 & 6272004.00 & 1714978.2400 & 831233.99655 \\
n Costs & & & & & 6864321.2126 \\
Environmental & 100 & 800000.00 & 35188206.00 & 5769236.2200 & 7 \\
Compensation Cost & 100 & -1.00 & 8.05 & .2681 & 1.18427 \\
Growth in Sales Volume & 100 & -.17 & 1.04 & .1023 & .16943 \\
Return on Assets & 100 & & & & \\
Valid N (listwise) & & & & \\
\hline
\end{tabular}

The descriptive statistics revealed that the average waste management/remediation Costs is $\$ 1714978.2400$ with maximum cost of $\$ 6272004.00$ and a minimum of $\$ 188543.00$. the statistic indicates that Environmental Compensation Cost has an average of $\$ 5769236.2200$ with maximum cost of $\$ 35188206.00$ and a minimum of $\$ 800000.00$. This means that petroleum marketing companies actually carried out environmental accounting. Growth in Sales Volume has an average of $0.2681 \%$ with a maximum of $8.05 \%$ and a minimum of $1.00 \%$ (-ve). Finally, Return on Asset has an average of $0.1023 \%$ with a maximum of $1.04 \%$ and a minimum of $0.17 \%$.(-ve)

\section{Data Analysis}

\section{Test of Hypothese}

To study adopted a multiple regression with Ordinary Least square. Table 4.2 presents a summary of the model specified extracted from the SPSS statistic version 20.0 output (see appendix I - IV).

Table 4.2: Extract of the Model specified (model 1 - 1V)

$\mathrm{GSV}=\mathrm{b}_{0}+\mathrm{b}_{1} \mathrm{WMRC}+\mathrm{b}_{2} \mathrm{ECC}+\mathrm{e}$

$\begin{array}{llllll} & \mathbf{R}^{2} & \text { Beta } & \mathbf{t} & \text { Sig. (2-tailed) } & \mathbf{f} \\ \text { WMRC } & .010 & -.098 & -.971 & .334 & .943 \\ \text { ECC } & .002 & -.048 & -.472 & .638 & .223 \\ \text { ROA = } \mathrm{b}_{0}+\mathrm{b}_{1} \text { WMRC + } \mathrm{b}_{2} \mathrm{ECC}+\mathrm{e} & & & & & \\ \text { WMRC } & .007 & -.081 & -.804 & .423 & .646 \\ \text { ECC } & .010 & -.101 & -1.001 & .319 & 1.001\end{array}$




\section{Hypothesis One}

The first hypothesis of the present study posits that there is no relationship between Amount Spent on waste management/remediation and growth in sales volume. Utilizing the regression output above, Amount Spent on waste management/remediation has a negative $(\mathrm{B}=-.098 \mathrm{t}=-.971 ;$ Sig. $=.334)$ relationship with growth in sales volume and judging by the significance level of .334 which is greater than the 0.05 significance level as depicted in the regression table above, the study therefore rejected the null hypothesis and concludes that, there is a relationship between Amount Spent on waste management/remediation and growth in sales volume

\section{Hypothesis Two}

The second hypothesis of the present study posits that there is no relationship between the amount spent on waste management / remediation and return on assets. From the regression output above, Amount Spent on waste management/remediation has a negative (B $=-.081 ; \mathrm{t}=-.804 ;$ Sig. $=.423$ relationship with Return on assets, however, judging by the significance level of .423 which is greater than the 0.05 significance level as depicted in the regression table above, the study therefore concludes; There is relationship between Amount Spent on waste management/remediation and returns on assets but not significant. The null hypothesis was rejected

\section{Hypothesis Three}

The third hypothesis of the present study states that there is no relationship between amount spent on compensation and growth in sales volume. Utilizing the regression output above, amount spent on compensation ( $\mathrm{B}=-.048 ; \mathrm{t}=-.472 ;$ Sig. $=.638)$ negatively and insignificantly relate with growth in sales volume. The study therefore rejected the null hypothesis and concludes there is a relationship between amount spent on compensation and growth in sales volume.

\section{Hypothesis Four}

The fourth hypothesis of the present study states that there is no relationship between amount spent on compensation and Return on Assets. From the extract of the analysis above, amount spent on compensation $(\mathrm{B}=-.101 ; \mathrm{t}=-1.001$; Sig. $=.319)$ negatively but insignificantly relate with Return on assets. The study therefore rejected the null hypothesis and concludes that there is a relationship between amount spent on compensation and Return on Assets.

\section{Discussion of findings}

The present study examined statistically the relationship between Environmental Accounting and Performance of Oil and Gas petroleum marketing companies in Nigeria from 2011-2020. Environmental accounting was measured with waste management/remediation cost and Environmental compensation cost while performance was represented by Growth in sales volume and ROA. Multiple regression analysis was employed. Based on the hypotheses tested, the result revealed that; 


\section{For Hypothesis One}

\section{There is no relationship between Amount Spent on waste management/remediation and} growth in sales volume.

The result of the test of this hypothesis revealed that there is a relationship between Amount Spent on waste management/remediation and growth in sales volume but negative and insignificant. The apriori expectation of the researcher was that the more you continue to manage your waste in line with the global best practices, the resultant effect would be an increase in sales since according to Chouhan (2005), many people are willing to pay more for a product that is environmentally friendly but the result revealed that the money spent on waste management / remediation does not contribute positively to the growth in sales volume.

The implication is that a unit increase in amount spent on waste management / remediation reduced the revenue by .334. This is in line with the position of Norhasimah et'al (2015) and Ifurueze, Lyndon and bingilar (2013).

\section{For hypothesis Two,}

There is no relationship between Amount Spent on waste management/remediation and returns on assets. The result of the second hypothesis reveals that there is a relationship, though negative but not significant. The apriori expectation of the researcher and which is in line with the position of Bassey et' al (2013), examined the impact of environmental accounting and reporting on organizational performance of Oil and Gas companies and their study shows that environmental accounting cost management positively influence firm's profitability after using Pearson's moment correlation analysis statistics for their analysis.

The implication of our own result is that amounts spent on waste management and remediation does not necessarily contribute positively to the ROA. This result is in line with the position of Norhasimah et'al (2015) and Adediran and Alade (2013) when they examined the impact of environmental accounting on corporate performance in Nigeria and their study showed a significant negative relationship between environmental accounting and return on capital employed (ROCE) and (EPS).

\section{For hypothesis three,}

There is no relationship between amount spent on compensation and growth in sales volume.

The result of the third hypothesis revealed that there is a relationship between amount spent on compensation and growth in sales volume but negative and insignificant. The implication is that amount spent on compensation does not increase sales volume. This result is in line with the position of Adediran and Alade (2013).

\section{For hypothesis four,}

\section{There is no relationship between amount spent on compensation and return on asset.}

The result of the test of this hypothesis shows that there is a negative and insignificant relationship between amount spent on compensation and Return on Assets. The implication is that amount spent on community development does not contribute to the return on asset. This 
result is in line with the findings of Daniel and Ambrose (2013) and Holm and Rikhardsson (2008), who studied the effect of environmental disclosure on investment decisions. Their results suggest that environmental information disclosure influences investment allocation decisions. Their findings would imply that companies that are apathetic to their environmental costs or responsibility might experience eventual crashes on their stock price if their investors are rational in considering the future value of the firm based on its present state of environmental responsibility

Generally, the relationship between the predictor and criterion variables is inverse (negative). Our expectation in line with other literatures was a positive relationship. However, not all social investments may yield return in financial form but may boost corporate competitive strategy and be of strategic value. Hillman and keim (2001).

\section{SUMMARY, CONCLUSION AND RECOMMENDATIONS}

\section{Summary}

This study adopted multiple regression analysis models with ordinary least square for the main reason of explaining statistically the relationship between environmental accounting and performance of oil and Gas companies listed on the floor of the Nigerian stock Exchange. The discoveries of the investigation were based on the records collected for the period 20112020 from all the listed oil and Gas firms in Nigeria. The study therefore summarizes that environmental accounting has effect on the performance of oil and Gas companies in Nigeria as a whole.

\section{Conclusions}

In line with the analyses and testing of the hypotheses, the study concludes as stated below that;

1. There is relationship between amount spent on waste management/remediation and growth in sales volume during the period of study.

2. There is a negative relationship between amounts spent on waste management/remediation and returns on assets but not significant during the period studied.

3. There is a negative but insignificant relationship between amount spent on compensation and growth in sales volume during the period studied.

4. There is a negative but insignificant relationship between amount spent on compensation and return on assets during the study period.

The study therefore concludes that environmental accounting has relationship with the performance of oil and Gas companies though not significant during the period studied. 


\section{RECOMMENDATIONS}

The study therefore makes the following recommendations:

1. The oil and Gas companies should continue to manage their waste properly in line with global best practices since it makes them socially acceptable and strategically positioned.

2. Compensation by way of community development costs should always be considered in the firms' decision-making process whether it contributes positively to both growths in sales volume and return on assets within the period or not.

3. Environmental accounting in all aspect should not be ignored as it creates a win-win relationship between the oil and Gas firms and the host communities over time.

\section{REFERENCES}

Abdul-Rahman, F. (2014). Reduce, Reuse, and Recycle: Alternatives for waste management. Guide G-314.

Adediran, S.A and Atu, O.K (2010). "Corporate Environmental Responsibility as a means of Alleviating Niger Delta Crises" Academic Scholarship Journal 2 (1).

Adediran, S.A. \& Alade, S.O (2013). The Impact of Environmental Accounting on Corporate Performance in Nigeria. European Journal of Business and Management. 6 (23)141151.

Aina, E.O.A (1991): The Making of Nigerian Environmental Policy FEPA.

Monograph/Federal Environmental Protection Agency.

Akhaiyea, (2009). "Design and Bases of Environmental Accounting in Oil and Gas and Manufacturing Sectors in Nigeria" Ph.D Dissertation, Covenant University, Ota, Nigeria. Retrieved http://eprints.

Convenantunversity.edu.ng/25/1environmentalaccountngdesignpdf on January 28 , 2017.

Al-Tuwaiji, S.A Christensen, T.E and Hughes II, K.E (2004). The Relations Among Environment Disclosure, Environmental Performance and Economic Performance: $A$ Simultaneous Equation Approach, Accounting, Organizations and Society 29: 447-471.

Ayoib, C. Nosakhare, P.O and Chijoke, O.M (2015). Environmental Accounting and Firm Profitability in Nigeria. Do firm- Specifics effects matters?. The IUP Journal of Accounting Research \& Audit Practices, 14(1)4.

Bassey, E. B, Sunday, O.E \& Mefor I.P (2012). The Impact of Environmental Accounting and Reporting on Sustainable Development in Nigeria. Research Journal of Finance and Accounting.3. (7).

Bewley, K. \& Li, Y (2000). Disclosure of Environmental Information by Canadian Manufacturing Companies. A Voluntary Disclosure Perspective. Advances in Environmental Accounting and Management. 1 (3)26-45.

Bontoux, L. \& Leone, F. (1997). The legal definition of waste and its impact on waste management in Europe. Institute for prospective Technological studies. A report prepared by IPST for the committee for environment, public Health and consumer protection of the European parliament. 
Carool, A.B (1991)" The Pyramid of Corporate Social Responsibility: Toward the moral Management of Organization Stakeholder". Business Horizons 3(4) 39-48.

Couhen. M (2005). The Chartered Accountant Conference, New York. 720-726.

Daniel, M.M \& Ambrose J.(2013). Environmental accounting and firm profitability: An empirical Analysis of selected firms listed in Bombay Stock Exchange, India. International journal of humanities and social science. 3 (18)248-256.

Deegan C. (2002). The Legitimizing Effect of Social and Environmental Disclosure - A Theoretical Foundation; Accounting, Auditing and Accountability, Journal. 15(3)282311.

EPA (Environmental Protection Agency (1995). An Introduction to Environmental Accounting as a Business Management Tool. Key Concepts and Terms, Office of Pollution Prevention and Toxics, EPA 742-R-95-001, June.

Freeman, A.B (1983). Towards and Epistemology for Radical Accounting: Beyond Objectivism and Relativism. Critical Perspective on Accounting.6 (1)485-496.

Freeman, R. (1984). Strategic Management. A Stakeholder Approach, Pitman, Boston.

Freeman. M. (1998). "Accounting and the Reporting of Pollution Information", Advances in Public Interest Accounting: 5,31- 43.

Global Reporting Initiative (GRI). (2002), Sustainability Guidelines on Economic, Environmental and Social Performance. GRI; Boston, MA.

Gray, R.H,Bebbington, J.\&Walter, D. (1993).Accounting for the environment. Paul chapman publishing, London.

HICPA (Hong Kong Institute of Certified Public Accountants (2004). The Consideration of Environmental Matters in the Audit of Financial Statements", Retrieved from www.likicpa.org.hk)ebork/HKSA_members-Handbook_master/volumell/pn1010. on March 2,2017)

Hillman, A. J \& Keim, G.D. (2001). Shareholders value, stakeholders management and social issues: what's the bottom line? Strategic management journal. 22(2)125239.

Holm, C., \& Rikhardsson, P. (2008). Experienced and Novice Investors: Does Environmental Information Influence Investment Allocation Decisions? European Accounting Review, 17(3), 537-557.

Ifurueze ,M.S.K, Lyndon, M.E \& Bingilar, P.F (2013). The impact of environmental cost on corporate performance: A study of oil companies in Niger Delta states in Nigeria. Journal of Business and management. 2(2)1-10.

Kothari C.R. \& Gaurav G. (2014). Research Methodology, Methods and Techniques. New Age International Publishers. New Delhi, P2.

KPMG, United Nations Environment Programme (UNEP) (2006). Carrots and Sticks for Starters: Current Trends and Approaches in Voluntary and Mandatory Standards for Sustainability Reporting. Park town: KPMG.

Macve, R. \& Carey, A (1992). Business, Accountancy and the Environment. A Policy and Research Agenda, Institute of Chartered Accountants, England and Wales.

Magara,N.N, Aming'a \& Momanyi .E (2015). Effects of environmental accounting on company financial performance in Kisii county. British journal of economics, management \& trade.10 (1)1-11.

Makori, D. M \& Jagongo, A. (2013). Environmental Accounting and Firm Profitability: An Empirical Analysis of Chosen Firms, Listed on Bombay Stock Exchanges, India", International Journal of Humanities and $\quad$ Social Science, 3 (8)248-256. 
Michael, G. Brian, U and Deigan, N (2011). Accounting Theory and Practice $\left(8^{\text {th }}\right.$. ed $)$ Ashford Colour Press Ltd, Gosport. Great Britain.

Myers N. (1989): Emergent Issue of Environmental Economics- what we should be analyzing closely but haven't thought much about. International Journal of Social Economics. 25 (6) $1271-1278$.

Norhasimah M.N et'al (2016). The effects of environmental disclosure on financial performance in Malaysia. procedia economics and finance. 35,117-126.

O’Donovan G; (2002). Environmental Disclosures in the Annual Report. Extending the Applicability and Predictive Power of Legitimacy Theory. Accounting, Auditing and Accountability Journal, 15(3)344-371.

Pramanike A; Shil. N and Das. B (2007). Environmental Accounting and Reporting with Special Reference to India. Munich Personal Repec Archive.7712.

Schalteegger, S. \& Burrit, R (2000). Contemporary environmental accounting. Sheffield, UK: Greenleaf publishing.

Suchman, M. (1995). "Localism and Globalism in Institutional Analysis: The Emergence of Contractual Norms in Venture Finances', in W Scott and S. Chriatenses (Eds), The Institutional Construction of Organizations. Internal and Longitudinal Studies, Sage. Publication, Thousand Oaks. C.A.

Tapang, A. T; Bassey, B.E. \& Bessong, P.K (2012). Environmental Activities and its Implications on the Profitability of Oil Companies in Nigeria. International Journal of Physical and Social Sciences, 2(3)285-302.

Teri (2001). India's Greenest Companies: A BT- TERI Project, BT-TERI 2001. Survey of Indian Industries, May 6, 2001.

Tharaman, A, Mahamed, I \& Sara Vamam, A.S (2007). Environmental Accounting as Tool for Environmental Management System. Journal of Applied Science, Environment and Management. 2 (2)137-145.

Tilt, C.A (1994). The influence of external pressure on corporate social disclosure. Accounting, Auditing, \& Accountability journal. 7(4)47-72.

Wikipedia (2017). Land Degradation. Retrieved in March 2017. http//en/Wikipedia.org.

Williams S.M (1999). Voluntary environmental and social disclosure practices in the Asiapacific Region: An international empirical Test of political economy theory. The international journal of Accounting, 34(2)209-238. 


\section{APPENDICES}

\section{APPENDIX 1}

\section{Model Summary}

\begin{tabular}{|l|r|r|r|r|}
\hline Model & \multicolumn{1}{|c|}{$\mathrm{R}$} & $\mathrm{R}$ Square & $\begin{array}{c}\text { Adjusted R } \\
\text { Square }\end{array}$ & $\begin{array}{c}\text { Std. Error of } \\
\text { the Estimate }\end{array}$ \\
\hline 1 & $.098^{\mathrm{a}}$ & .010 & -.001 & 1.18461 \\
\hline
\end{tabular}

a. Predictors: (Constant), waste management/remediation

Costs

ANOVA ${ }^{\mathrm{a}}$

\begin{tabular}{|c|c|c|c|c|c|}
\hline Model & $\begin{array}{c}\text { Sum of } \\
\text { Squares }\end{array}$ & Df & Mean Square & $\mathrm{F}$ & Sig. \\
\hline $\begin{array}{l}\text { Regression } \\
\text { Residual } \\
\text { Total }\end{array}$ & $\begin{array}{r}1.324 \\
137.523 \\
138.847\end{array}$ & $\begin{array}{r}1 \\
98 \\
99\end{array}$ & $\begin{array}{l}1.324 \\
1.403\end{array}$ & .943 & $.334^{\mathrm{b}}$ \\
\hline
\end{tabular}

a. Dependent Variable: Growth in Sales Volume

b. Predictors: (Constant), waste management/remediation Costs

\section{Coefficients $^{\mathrm{a}}$}

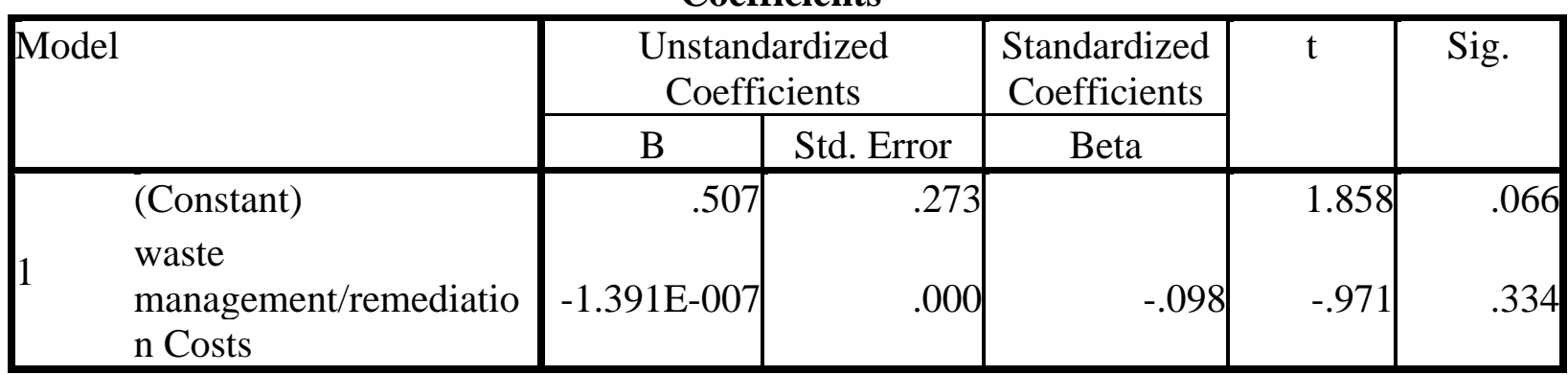

a. Dependent Variable: Growth in Sales Volume 


\section{APPENDIX 11}

\section{Model Summary}

\begin{tabular}{|l|r|r|r|r|}
\hline Model & \multicolumn{1}{|c|}{$\mathrm{R}$} & R Square & $\begin{array}{c}\text { Adjusted R } \\
\text { Square }\end{array}$ & $\begin{array}{c}\text { Std. Error of } \\
\text { the Estimate }\end{array}$ \\
\hline 1 & $.081^{\mathrm{a}}$ & .007 & -.004 & .16973 \\
\hline
\end{tabular}

a. Predictors: (Constant), waste management/remediation Costs

\section{ANOVA ${ }^{a}$}

\begin{tabular}{|c|c|c|c|c|c|}
\hline Model & $\begin{array}{l}\text { Sum of } \\
\text { Squares }\end{array}$ & Df & Mean Square & $\mathrm{F}$ & Sig. \\
\hline $\begin{array}{ll} & \text { Regression } \\
1 & \text { Residual } \\
\text { Total }\end{array}$ & $\begin{array}{r}.019 \\
2.823 \\
2.842\end{array}$ & $\begin{array}{r}1 \\
98 \\
99\end{array}$ & $\begin{array}{l}.019 \\
.029\end{array}$ & .646 & $.423^{b}$ \\
\hline
\end{tabular}

a. Dependent Variable: Return on Assets

b. Predictors: (Constant), waste management/remediation Costs

\section{Coefficients $^{\text {a }}$}

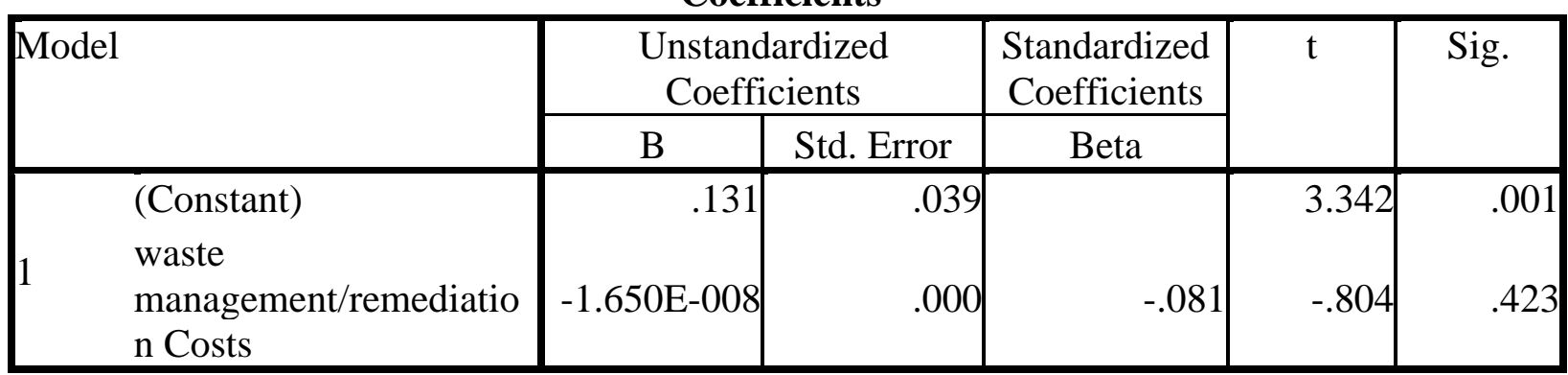

a. Dependent Variable: Return on Assets

\section{APPENDIX 111}

\section{Model Summary}

\begin{tabular}{|l|r|r|r|r|}
\hline Model & \multicolumn{1}{|c|}{$\mathrm{R}$} & R Square & $\begin{array}{c}\text { Adjusted R } \\
\text { Square }\end{array}$ & $\begin{array}{r}\text { Std. Error of } \\
\text { the Estimate }\end{array}$ \\
\hline 1 & $.048^{\mathrm{a}}$ & .002 & -.008 & 1.18894 \\
\hline
\end{tabular}

a. Predictors: (Constant), Environmental Compensation

Cost 
ANOVA ${ }^{\mathrm{a}}$

\begin{tabular}{|c|c|c|c|c|c|}
\hline Model & $\begin{array}{l}\text { Sum of } \\
\text { Squares }\end{array}$ & Df & Mean Square & $\mathrm{F}$ & Sig. \\
\hline $\begin{array}{l}\text { Regression } \\
\text { Residual } \\
\text { Total }\end{array}$ & $\begin{array}{r}.315 \\
138.532 \\
138.847\end{array}$ & $\begin{array}{r}1 \\
98 \\
99\end{array}$ & $\begin{array}{r}.315 \\
1.414\end{array}$ & .223 & $.638^{\mathrm{b}}$ \\
\hline
\end{tabular}

a. Dependent Variable: Growth in Sales Volume

b. Predictors: (Constant), Environmental Compensation Cost

\section{Coefficients $^{\mathrm{a}}$}

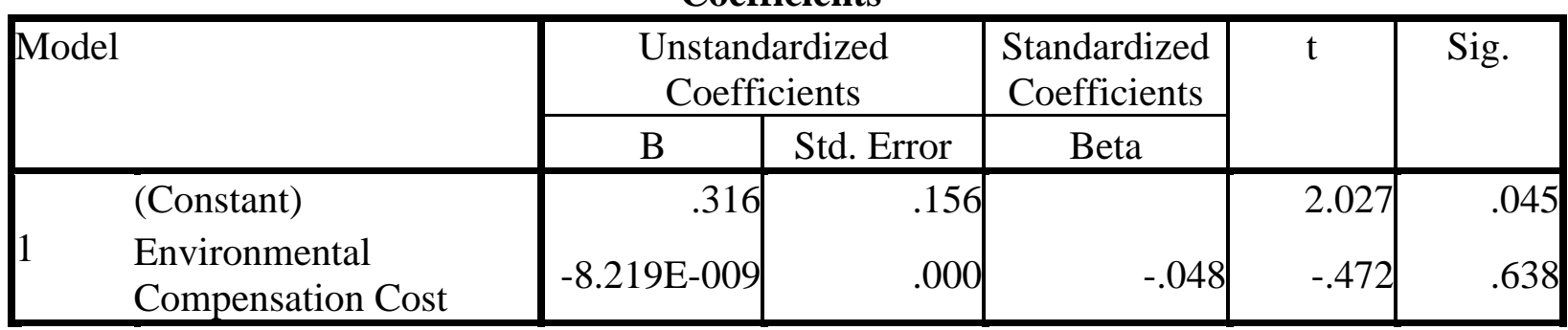

a. Dependent Variable: Growth in Sales Volume

\section{APPENDIX IV}

\section{Model Summary}

\begin{tabular}{|l|r|r|r|r|}
\hline Model & \multicolumn{1}{|c|}{$\mathrm{R}$} & R Square & $\begin{array}{c}\text { Adjusted R } \\
\text { Square }\end{array}$ & $\begin{array}{c}\text { Std. Error of } \\
\text { the Estimate }\end{array}$ \\
\hline 1 & $.101^{\mathrm{a}}$ & .010 & .000 & .16943 \\
\hline
\end{tabular}

a. Predictors: (Constant), Environmental Compensation

Cost

ANOVA ${ }^{a}$

\begin{tabular}{|c|c|c|c|c|c|}
\hline Model & $\begin{array}{l}\text { Sum of } \\
\text { Squares }\end{array}$ & Df & Mean Square & $\mathrm{F}$ & Sig. \\
\hline $\begin{array}{l}\text { Regression } \\
\text { Residual } \\
\text { Total }\end{array}$ & $\begin{array}{r}.029 \\
2.813 \\
2.842\end{array}$ & $\begin{array}{r}1 \\
98 \\
99\end{array}$ & $\begin{array}{l}.029 \\
.029\end{array}$ & 1.001 & $.319^{b}$ \\
\hline
\end{tabular}

a. Dependent Variable: Return on Assets

b. Predictors: (Constant), Environmental Compensation Cost 


\section{Coefficients $^{\mathrm{a}}$}

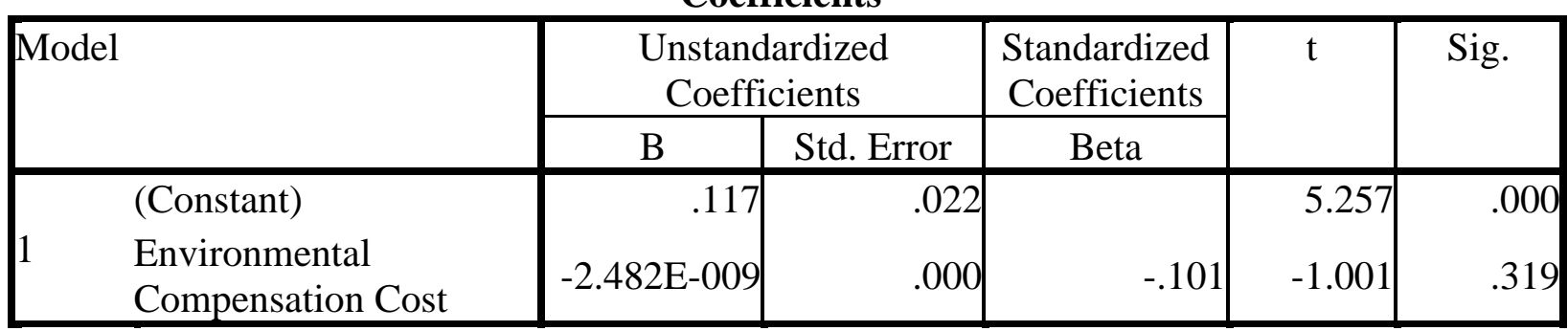

a. Dependent Variable: Return on Assets

\section{APPENDIX 1}

\section{Model Summary}

\begin{tabular}{|l|r|r|r|r|}
\hline Model & \multicolumn{1}{|c|}{$\mathrm{R}$} & $\mathrm{R}$ Square & $\begin{array}{c}\text { Adjusted R } \\
\text { Square }\end{array}$ & $\begin{array}{r}\text { Std. Error of } \\
\text { the Estimate }\end{array}$ \\
\hline 1 & $.009^{\mathrm{a}}$ & .000 & -.010 & .41656 \\
\hline
\end{tabular}

a. Predictors: (Constant), waste management/remediation Costs

ANOVAa

\begin{tabular}{|c|c|c|c|c|c|}
\hline Model & $\begin{array}{l}\text { Sum of } \\
\text { Squares }\end{array}$ & Df & Mean Square & $\mathrm{F}$ & Sig. \\
\hline $\begin{array}{l}\text { Regression } \\
\text { Residual } \\
\text { Total }\end{array}$ & $\begin{array}{r}.002 \\
17.005 \\
17.007 \\
\end{array}$ & $\begin{array}{r}1 \\
98 \\
99\end{array}$ & $\begin{array}{l}.002 \\
.174\end{array}$ & .009 & $.925^{\mathrm{b}}$ \\
\hline
\end{tabular}

a. Dependent Variable: Growth in Sales Volume

b. Predictors: (Constant), waste management/remediation Costs

\section{Coefficients $^{\mathrm{a}}$}

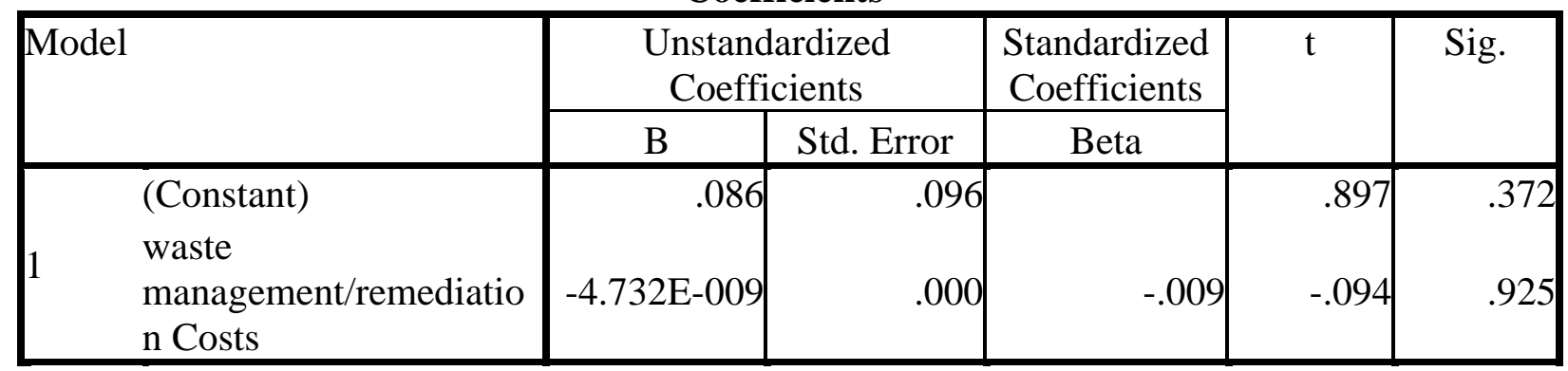

a. Dependent Variable: Growth in Sales Volume 
African Journal of Accounting and Financial Research

ISSN: 2682-6690

Volume 4, Issue 2, 2021 (pp. 26-54)

www.abjournals.org

\section{APPENDIX 11}

Model Summary

\begin{tabular}{|l|r|r|r|r|}
\hline Model & \multicolumn{1}{|c|}{$\mathrm{R}$} & $\mathrm{R}$ Square & $\begin{array}{c}\text { Adjusted R } \\
\text { Square }\end{array}$ & $\begin{array}{r}\text { Std. Error of } \\
\text { the Estimate }\end{array}$ \\
\hline 1 & $.052^{\mathrm{a}}$ & .003 & -.007 & .41601 \\
\hline
\end{tabular}

a. Predictors: (Constant), Environmental Compensation

Cost

ANOVA ${ }^{\mathrm{a}}$

\begin{tabular}{|c|c|c|c|c|c|}
\hline Model & $\begin{array}{l}\text { Sum of } \\
\text { Squares }\end{array}$ & Df & Mean Square & $\mathrm{F}$ & Sig. \\
\hline $\begin{array}{l}\text { Regression } \\
\text { Residual } \\
\text { Total }\end{array}$ & $\begin{array}{r}.047 \\
16.960 \\
17.007\end{array}$ & \begin{tabular}{r|}
1 \\
98 \\
99
\end{tabular} & $\begin{array}{l}.047 \\
.173\end{array}$ & .270 & $.604^{b}$ \\
\hline
\end{tabular}

a. Dependent Variable: Growth in Sales Volume

b. Predictors: (Constant), Environmental Compensation Cost

\section{Coefficients $^{\mathrm{a}}$}

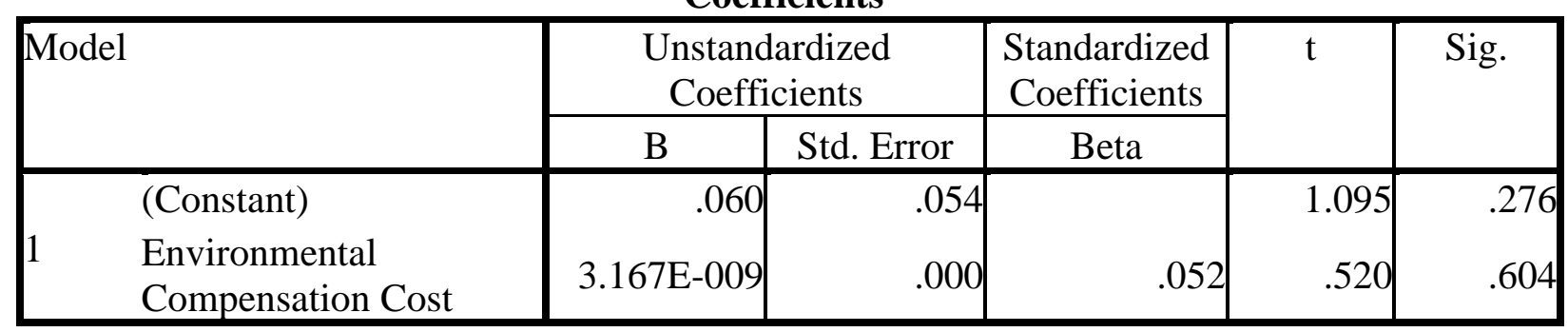

a. Dependent Variable: Growth in Sales Volume

\section{APPENDIX 111}

\section{Model Summary}

\begin{tabular}{|l|r|r|r|r|}
\hline Model & \multicolumn{1}{|c|}{$\mathrm{R}$} & $\mathrm{R}$ Square & $\begin{array}{c}\text { Adjusted R } \\
\text { Square }\end{array}$ & $\begin{array}{r}\text { Std. Error of } \\
\text { the Estimate }\end{array}$ \\
\hline 1 & $.085^{\mathrm{a}}$ & .007 & -.003 & .11352 \\
\hline
\end{tabular}

a. Predictors: (Constant), waste management/remediation

Costs 
African Journal of Accounting and Financial Research

ISSN: 2682-6690

Volume 4, Issue 2, 2021 (pp. 26-54)

www.abjournals.org

\begin{tabular}{|c|c|c|c|c|c|}
\hline \multicolumn{6}{|l|}{$A N O V A^{a}$} \\
\hline Model & $\begin{array}{c}\text { Sum of } \\
\text { Squares }\end{array}$ & $\mathrm{Df}$ & Mean Square & $\mathrm{F}$ & Sig. \\
\hline $\begin{array}{ll} & \text { Regression } \\
1 & \text { Residual } \\
\text { Total }\end{array}$ & $\begin{array}{r}.009 \\
1.263 \\
1.272\end{array}$ & $\begin{array}{r}1 \\
98 \\
99\end{array}$ & $\begin{array}{l}.009 \\
.013\end{array}$ & .718 & $.399^{b}$ \\
\hline
\end{tabular}

a. Dependent Variable: Return on Assets

b. Predictors: (Constant), waste management/remediation Costs

\section{Coefficients $^{\text {a }}$}

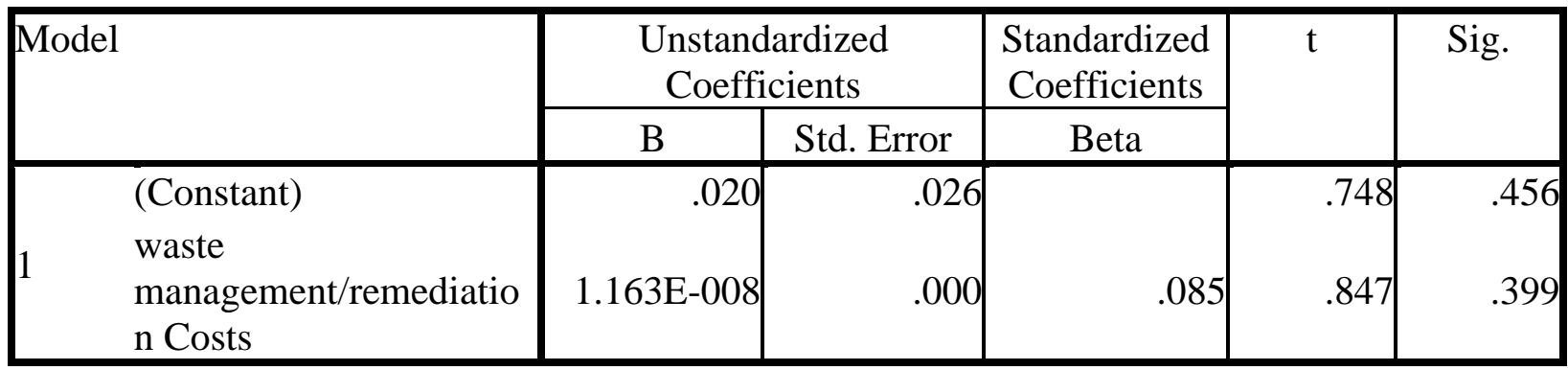

a. Dependent Variable: Return on Assets

\section{APPENDIX IV}

Model Summary

\begin{tabular}{|l|r|r|r|r|}
\hline Model & \multicolumn{1}{|c|}{$\mathrm{R}$} & R Square & $\begin{array}{c}\text { Adjusted R } \\
\text { Square }\end{array}$ & $\begin{array}{c}\text { Std. Error of } \\
\text { the Estimate }\end{array}$ \\
\hline 1 & $.021^{\mathrm{a}}$ & .000 & -.010 & .11391 \\
\hline
\end{tabular}

a. Predictors: (Constant), Environmental Compensation

Cost

ANOVA ${ }^{\mathrm{a}}$

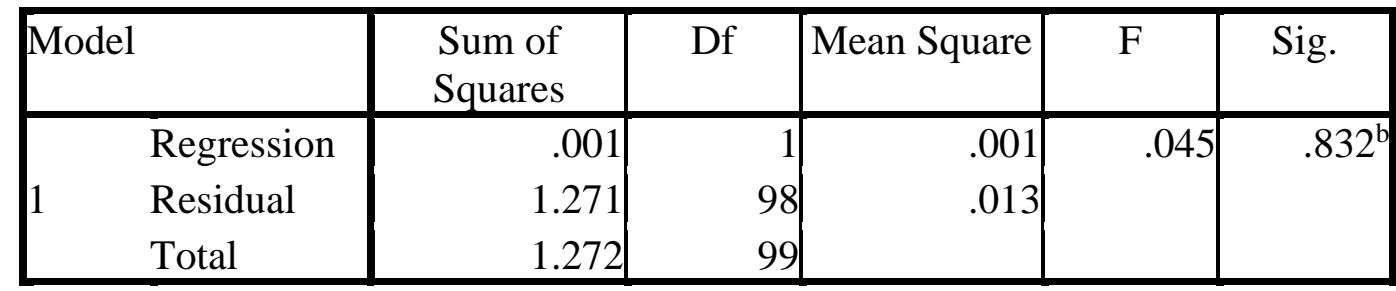

a. Dependent Variable: Return on Assets

b. Predictors: (Constant), Environmental Compensation Cost 
African Journal of Accounting and Financial Research

ISSN: 2682-6690

Volume 4, Issue 2, 2021 (pp. 26-54)

www.abjournals.org

Coefficients $^{\mathbf{a}}$

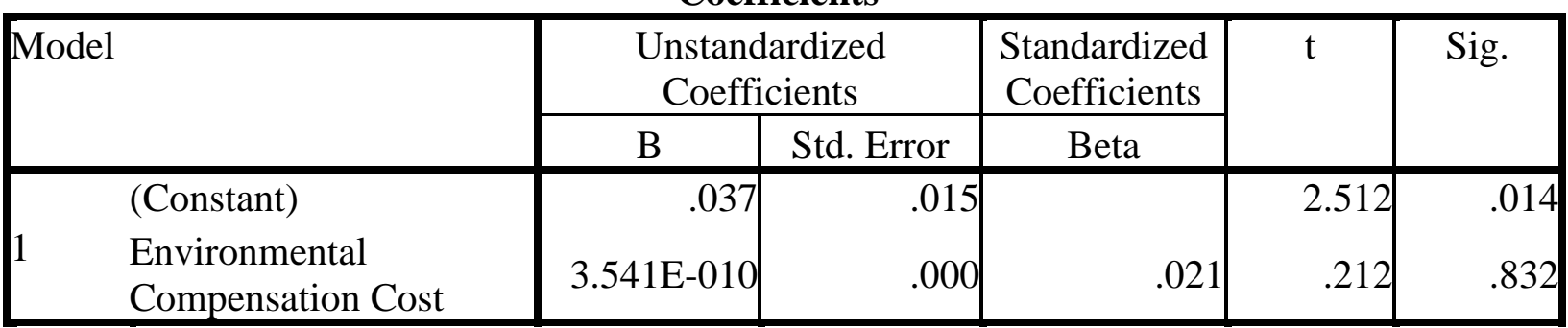

a. Dependent Variable: Return on Assets 